\title{
Factors Affecting the Implementation of Nursing Practice Policies in Lamongan
}

\section{Dadang Kusbiantoro \\ Universitas Muhammadiyah Lamongan}

\section{ORCID}

Dadang Kusbiantoro: https://orcid.org/0000-0002-6986-4419

Corresponding Author: Dadang Kusbiantoro; email: dadangkusbiantoro123@gmail.com

Published: 7 February 2022

Publishing services provided by Knowledge E

(c) Dadang Kusbiantoro. This article is distributed under the terms of the Creative Commons Attribution License, which permits unrestricted use and redistribution provided that the original author and source are credited.

Selection and Peer-review unde the responsibility of the IVCN Conference Committee.
G OPEN ACCESS
Abstract. Problems in nursing practices are very complex, ranging from administrative problems to competencies and limits of authority. The purpose of this study was to analyze the supporting and inhibiting factors of nursing practices in Lamongan Regency. Descriptive qualitative methods were used with a phenomenological approach. The data were obtained from: 1) PPNI Lamongan District Legal and Political Affairs; 2) Staff of Health Human Resources (SDMK) Lamongan District Health Office; 3) Lamongan Regency Licensing Office; 4) independent practice nurses; and 5) from the public. The data were collected through interviews, observations, and document studies. According to the results, the supporting factors include the forms of legislation that provide clarity on the important role of health workers. Ministerial regulations and regional regulations concerning licensing and implementation of independent nurse practices are urgently needed to provide legal certainty to nurses. The inhibiting factors include: 1) the problem of limiting authority between nursing and medical practice; 2) public perceptions of nursing practices; 3) perceptions of complicated licensing practices; 4) types and competencies of nurses; and 5) increases in health service facilities. There is a need for coordination between the Government, the Ministry of Health, the Health Service, and PPNI to facilitate, supervise and provide guidance in the implementation of independent nurse practices.

Keywords: factor, policy, nursing practice

\section{Introduction}

Nursing services are based on the philosophy of humanity. Nursing practice must be carried out based on professional standards, nursing knowledge and tips, and adhering to the ethics of the nursing profession. Nursing services include promotive, preventive, curative and rehabilitative efforts. Nurses are are one of the largest health workers and are spread in almost all regions. Nurses' education varies from Health Nursing School (SPK), Diploma, Bachelor, Profession to specialists [1].

Based on the classification of educational levels in Indonesia, there are $77.56 \%$ nurses without professional education including diploma and bachelor graduates, $10.84 \%$ nurses graduated from bachelor program with professional education, 5.17\% nurses graduated from Health Nursing School (SPK), and only $6.42 \%$ are specialist 
nurses. In Lamongan, most of the nurses (59.21\%) are diploma graduates and 50.63\% of the nurses work in the government. Some of the nurses $(28.12 \%)$ run independent practice and most of them (71.88\%) do not open independent practice.

The problems that occur today are related to the management of nurse practice licenses including: 1). There are still nurses who do not have Nursing Practice License (SIPP) but carrying out nursing practice . 2). Nurses with expired SIPP did not reapply the license because some conditions are not met 3) Nurses whose SIPP is written at the old workplace, yet the nurse concerned has moved to a new health service. 4). The legal basis for implementing independent nursing practice already exists, but there are still many nurses who do not open independent practice [2].

For this reason, it is necessary to make efforts to realize the independent practice of nurses in accordance with regulations, codes of ethics and professional standards.

\section{Research Methods}

The research applied descriptive qualitative with a phenomenological approach. The data were obtained from informants and document studies which included 1). Legal and Politics sector of the Indonesian Nurses Association (PPNI) of Lamongan, 2). Staff of Health Human Resources (SDMK) Lamongan District Health Office, 3). Lamongan Regency Licensing Office, 4). Independent practice nurse, 5). Public. The data were collected through interviews, observations and through document studies. The data were analyzed by triangulation and then concluded [3].

\subsection{Research Results and Discussions}

\section{Discussion}

\subsection{Supporting Factors for Nursing Practice Policy}

Legislation has provided clarity on the important role of health workers in general and nurses in particular in carrying out their skills in accordance with existing competencies to provide health services. Nurses as a part of health workers whose existence is recognized by law, are given authority in accordance with the educational competence they have obtained to provide health services in the regions. Therefore, it is necessary to regulate their rights and obligations. For this reason, nurses who work in accordance with professional standards need to get legal protection. The nurse must first have a 
TABLE 1

\begin{tabular}{ll} 
No Factors & Important Findings \\
\hline Sommunication & $\begin{array}{l}\text { There is clear and open communication between } \\
\text { the nursing professional association (PPNI) and the } \\
\text { Lamongan Regency Health Office and Licensing Office. } \\
\text { Some people think that nurses are doctors. Some } \\
\text { people think that obtaining a nurse practice license } \\
\text { is complicated and convoluted. People and other } \\
\text { professions do not understand that there are regulations } \\
\text { concerning independent nurses practice. }\end{array}$ \\
\hline The number of vocational graduate nurses who taking \\
professional education has increased. Developing nurs- \\
ing practice by attending formal and non-formal nursing \\
education and continuing education Different types of \\
nurses with different scope of authority Differences in \\
the competence of vocational nurses and professional \\
nurses that are contrary to their clinical experience The \\
number of health facilities has increased. Some nurses \\
who work in health care facilities do not have a nurse \\
practice license.
\end{tabular}

permit and must always be fostered and supervised, so that they can carry out thier duties in accordance with the policies of the legislation and the system that has been established. All forms of irregularities committed by nurses who are not in accordance with the code of ethics, professional standards and laws, will have consequences in the form of administrative and legal sanctions [4].

The Regional Regulation on Licensing and Implementation of Independent Nurse Practices is very much needed to provide legal certainty to nurses, and especially to the community in Lamongan Regency. Through this Regional Regulation, it is hoped 
that quality and affordable health services can be created in accordance with the limits of competence and professional standards of nurses. The substances regulated in this Regional Regulation are in line with the laws and regulations at the central level, which are accommodated with the potential, character and conditions of the uniqueness of the Lamongan Regency area.

The local government's support in implementing the policy for managing Nurse Practice License in Lamongan Regency has been good. All parties involved in implementing the policy have played their proper role. Policy implementors include the nursing profession organization in this case the Indonesian National Nurses Association (PPNI) in Lamongan Regency, the Lamongan District Health Office and the Lamongan Regency One Stop Integrated Licensing Service. There is already a division of roles and functions among the implementing institutions for the policy of administering the Nurse Practice License. The nursing profession organization, PPNI, has played a role in providing recommendations for the management of SIPP. The Health Office plays a role in providing recommendations while the One Stop Integrated Licensing service plays a role in issuing SIPP on the recommendation of the authorized health official, in this case the health office [5].

To increase consolidation among nurses who opened independent Nursing Practices in 2018, a Communication Forum for Independent Practice Nurses (FKPPM) has been formed. This forum aims to communicate and convey all information and regulations related to independent nursing practice. This forum also accommodates and distributes the problems and obstacles in carrying out independent nursing practice. The representatives of this forum are invited when guidance and supervision from nursing professional organizations and the Lamongan District Health Office are held.

\subsection{Inhibiting Factors of Nurse Practice Policy}

\subsubsection{Problems Limiting the authority of Nursing and Medical Practice}

The nursing profession is one of the professions that is an integral part of the health care system. Nurses are professionals who have a special and specific body of knowledge. In carrying out their professional practice, nurses have responsibilities and accountability. They are also very bound by the rules governing the practice of health workers. Nurses as part of health workers contribute to health services through nursing practice. Nursing practice is a professional nursing action based on the rules of science, code of ethics and nursing ethics as a guideline for nurses in providing services to the community, so as to 
ensure that the community gets ethical and responsible services. Overlapping between the duties of doctors and nurses is still common. Besides, some nurses who graduated from higher education feel that they are in a gray area because there is no clarity about their roles, functions and authorities. This is what strengthens the assumption that all nurses have the same knowledge and skills regardless of their educational background, even though this assumption is wrong.

Regarding the nurses' practice permit, it has been regulated in the Nursing Act. However, the boundaries of nursing practice are still largely gray. Meanwhile, in the Nursing Act, nurses are allowed to take medical action only in emergency conditions. However, the fact is that there are nurses who go to prison because they fail to prove that their actions are an emergency. The reality in the field is that many legal cases occur during delegation actions. In the Draft Criminal Code Article 276 "Everyone who carries out a job resembling a doctor or dentist as a special or part-time source of income is sentenced to a minimum of 5 years imprisonment or a maximum fine of category $\mathrm{V}$. The word "resembling" in the article have multiple interpretations. What is meant by "resembling" is not a doctor who provides treatment.

\subsubsection{Perceptions of Complicated Licensing Services}

The fact shows that currently there is still a perception of the weaknesses which make the government services ineffective. These weaknesses include complicated services, unclear administrative requirements, lack of openness of procedures in obtaining services, less efficient services, and lack of fairness in service delivery. In addition, there are several factors that affect the quality of service including factors from the community, employee capabilities, applicable regulations and supporting facilities.

\subsubsection{Public Perceptions of Nurses and Doctors}

The types of nursing staff as referred to by the Health Personnel Act are composed of various types of nurses. In carrying out their practice nursing staff must be in accordance with their authority based on their competency standards. In certain circumstances, health workers can provide services outside their authority. In providing health services, health workers can receive delegation of medical actions from medical personnel. Public perception is a process that involves cognition, affection and community connection in responding to certain things or objects obtained through the five senses possessed, so that a picture of the object or subject is formed [6] . 


\subsubsection{Types and Competencies of Nurses}

The data shows that in Lamongan Regency most of the nurses (59.33\%) are vocational nurses and almost half (40.67\%) are professional nurses. Types of nurses consist of vocational nurses and professional nurses. Vocational nurses are nurses who graduate from nursing vocational education at least Diploma Three Nursing program. Vocational nurses are nurses who carry out nursing practice and have technical nursing skills in carrying out nursing care. Professional nurses are nurses who graduate from nursing professional education including a nursing profession program and a nursing specialist program. Professional nurses consist of Ners and specialist Ners. Ners are nurses who graduated from the nursing profession program who have special expertise in nursing care. Specialist nurses are nurses who graduate from a nursing specialist program who have special expertise in nursing care.

Nurses are one of the professions that work in the health sector which has its own competence, namely being able to provide nursing care to clients, both as individuals, families and communities, both healthy and sick. As a profession in the health sector, the policy regarding nurses is under the auspices of the Ministry of Health. The Ministry of Health has issued a Decree of the Minister of Health which contains the Standards of the Nursing Profession. In the regulation it is explained that the competence of nurses includes elements of knowledge, elements of attitudes and elements of skills [7].

Law No. 38 of 2014 concerning Nursing has explained that there are 2 types of nurses, namely vocational nurses and professional nurses. Although it has been declared to have passed the nurse competency test as evidenced by the possession of a Nurse Registration Certificate (STRP), the reality in the field shows that there is no difference in nursing practice between vocational nurses and professional nurses. In fact, sometimes vocational nurses with long work experience have much better skills than those who have just graduated. For this reason, competent human resources are needed.

\subsubsection{Increase in Health Service Facilities}

Along with the increase in population, of course, the need for health service facilities will increase. Lamongan district has health facilities in the form of 2 governmentowned hospitals, namely the Dr. Soegiri General Regional Hospital and Ngimbang Regional General Hospital, 10 Privately Owned Hospitals, 33 Community Health Centers (Puskesmas), and 70 Health Clinics. In addition, there are individual health practices 
in the form of general practitioners' practices, doctor's practices and independent midwives' practices.

\section{Conclusions}

Legislation provides clarity on the important role of health workers. Regional Regulations concerning Licensing and Implementation of Independent Nurse Practices are urgently needed to provide legal certainty to nurses. All parties involved in implementing the policy have played their proper role. Policy implementors include the nursing profession organization in this case the Indonesian National Nurses Association (PPNI) in Lamongan Regency, the Lamongan District Health Office and the Lamongan Regency One Stop Integrated Licensing Service [8]. There is a division of roles and functions among the implementing institutions for administering Nurse Practice License policy. The nursing profession association, PPNI, plays a role in providing recommendations for the management of SIPP. The Health Office plays a role in providing recommendations while the One Stop Integrated Licensing service plays a role in issuing SIPP on the recommendation of the authorized health official, in this case the health office. In 2018 an Independent Practice Nurse Communication Forum (FKPPM) was formed. The inhibiting factors include: 1). There is a problem concerning "gray area" between nursing and medical practice, 2). Public perception of nursing practice, 3). Perceptions of complicated licensing practices, 4). Types and Competencies of nurses 5). Increase in health service facilities in the community.

\section{Suggestions}

Coordination and collaboration are needed between the government, the ministry of health, the Health Service, and PPNI to facilitate, supervise and guide the implementation of the independent practice of nurses.

\section{References}

[1] Undang Undang Republik Indonesia nomor 36 tahun 2009 tentang kesehatan.

[2] Undang Undang Republik Indonesia nomor 36 tahun 2014 tentang tenaga kesehatan.

[3] Undang Undang Republik Indonesia nomor 38 tahun 2014 tentang keperawatan. 
[4] Peraturan Menteri Kesehatan Republik Indonesia nomor 26 tahun 2019 tentang peraturan pelaksanaan undang undang nomor 38 tahun 2014 tentang keperawatan.

[5] Keputusan Menteri Kesehatan Republik Indonesia nomor HK.01.07/MENKES/425/2020 tentang standart profesi perawat.

[6] Rachmawati, R., \& Astuti, P. Persepsi Masyarakat Terhadap Kebijakan Pengenaan Sanksi Biaya Paksa Terkait Penataan PkI Di Kasawan Kepatihan Kota Bandung. 2018. Journal of Politic and Government Studies, 5(02), 281-290.

[7] Peraturan Gubernur Jawa Timur nomor 4 tahun 2010 tentang pondok kesehatan desa di Jawa timur

[8] Peraturan Daerah Kabupaten Lamongan nomor 9 tahun 2018 tentang perizinan dan penyelenggaraan praktik mandiri perawat 